\title{
STUDI HABITAT BUAYA SENYULONG (Tomistoma schlegelii) DI SUNGAI SEKONYER TAMAN NASIONAL TANJUNG PUTING KALIMANTAN TENGAH
}

(Study of Senyulong Crocodile (Tomistoma schlegelii) Habitat in Sekonyer River Tanjung Puting National Park Central Kalimantan)

\author{
M. Bakti Saputro, Slamet Rifanjani, Sarma Siahaan \\ Fakultas Kehutanan Universitas Tanjung Pura Jl. Daya Nasional, Pontianak 78124 \\ E-mail : becktysaputra@gmail.com
}

\begin{abstract}
Senyulong (Tomistoma schlegelii) are crocodiles that have a unique morphology with shape of the snout in its mouth. This species based on IUCN Red List classified by endangered category (IUCN 2004). This study aim to determine characteristics ofSenyulong Habitat in Sekonyer river, Tanjung Puting National Park Central Kalimantan using by Purposive Sampling in discovery spot or ex crocodile nest, Parameter analyzed by important value index (INP), dominance index $(C)$, index species diversity $(H)$, species abundance index $(e)$, and species similarity index. The results showed the abiotic water habitats in the river water $\mathrm{pH} 6$ which indicated normal, an average of depth 4.5 meters and a water temperature $23.90{ }^{\circ} \mathrm{C}$. Biotically False Gharial likes the habitat of aquatic plants such as Rasau (Pandanus tectorious), water lily (Hanguana malayana) for sheltering. False gharial aquatic food habitats such as Toman fish (Channa gachua), Gabus (Channa striata) and Runtuk (Channa luchius) Baung (Mystus wyckii), Lais (Lais hexamena). Abiotically terrestrial habitats contain sandy clay texture and histosol soil types with 6 soil acidity, with 78\% air humidity and the average temperature of $29^{\circ} \mathrm{C}$. Biologically, Senyulong terrestrial habitat formed by buffer zone with large tree with wide canopy and several types of terrestrial animals Senyulong food such as long-tailed monkeys, orangutans, and wild pigs. The terrestrial habitat of False Gharial is an important place to spawning ground by placing its eggs under a large buttress tree and covering the nest with leaf litter to keep it warm to camouflage egg predators such as to monitor lizards.
\end{abstract}

Keyword: Terrestrial Habitat, Aquatic Habitat, Senyulong, Tanjung puting National Park

\section{PENDAHULUAN}

Buaya adalah reptil yang hidup didua habitat yaitu habitat darat dan air, bernafas dengan paru-paru dan berdarah dingin. Secara ilmiah buaya meliputi seluruh spesies anggota suku crocodylidae, termasuk pula buaya senyulong (Tomistoma schlegelii). Buaya Senyulong hidup di dataran rendah, danau dan sungai. Pertemuan yang paling banyak dijumpai di rawa gambut dan hutan rawa air tawar
(Stuebing, 2006). Makanan utama buaya adalah hewan-hewan bertulang belakang seperti bangsa ikan, reptil dan mamalia, terkadang juga memangsa moluska dan krustasea.

Buaya senyulong merupakan satu dari empat spesies buaya yang terdapat di Indonesia, buaya yang mempunyai morfologi yang sangat unik yaitu bentuk moncong di mulutnya. Buaya Senyulong dibeberapa daerah memiliki perbedaan nama seperti misalnya buaya 
jolong-jolong, buaya julung-julung, buaya ikan, dan buaya sapit. Buaya Senyulong merupakan buaya berukuran besar dengan penyebarannya di Indonesia dan Malaysia. Buaya ini merupakan buaya air tawar yang memiliki status vulnerable $A 2 c d$ dalam The IUCN Red List of Threatened Speciesт. Hal ini berarti Senyulong menghadapi resiko kepunahan yang tinggi di alam liar (IUCN, 2015). Dalam Convention on International Trade in Endangered Spesies of Wild Flora and Fauna (CITES), Senyulong termasuk dalam Appendix 1, menunjukkan buaya Senyulong/ terancam punah dan CITES melarang perdagangan internasional terhadap spesimen spesies ini (CITES, 2015).Secara umum diperhitungkan bahwa borneo dapat mendukung populasi-populasi buaya senyulong paling besar secara global, karena habitat hutan rawanya lebih besar dibanding Sumatra ataupun Semenanjung Malaysia.

Populasi global dari buaya air tawar asli daratan Sunda ini terus megalami penurunan yang yang diakibatkan oleh tingginya kegiatan manuasia (Aulia, dkk, 2006). Melihat kondisi dilapangan seperti ini sangat jelas bahwa usaha perlindungan dan pelestarian satwa liar saat ini masih jauh dari apa yang ingin dicapai karena sampai saat ini dalam usahanya belum maksimal baik itu dalam implementasinya, oleh karena itu dibutuhkan pergerakan dari berbagai pihak untuk menunjang dalam peningkatan perlindungan populasi dan habitat buaya yang kian hari semakin mengalami penurunan dan semakin terancam yang akan berujung pada punahnya hewan tersebut.

Buaya adalah reptil yang hidup didua habitat yaitu habitat darat dan habitat air, bernafas dengan paru-paru dan berdarah dingin. Secara ilmiah buaya meliputi seluruh spesies anggota suku crocodylidae, termasuk pula buaya senyulong (Tomistoma schlegelii). Pada umumnya buaya menghuni habitat perairan tawar seperti sungai, danau, rawa, dan lahan basah lainnya, namun ada juga yang hidup di air payau seperti buaya muara. Makanan utama buaya adalah hewan-hewan bertulang belakang seperti bangsa ikan, reptil dan mamalia, terkadang juga memangsa moluska dan krustacea.

Tujuan penelitian ini adalah mengumpulkan data mengenai karakteristik habitat buaya Senyulong yang berada di Sungai Sekonyer Kecamatan Kumai Taman Nasional Tanjung Puting Kalimantan Tengah.

\section{METODE PENELITIAN}

\section{Tempat dan Waktu Penelitian}

Penelitian ini dilakukan di Sungai Sekonyer Kecamatan Kumai, Kabupaten Kotawaringin Barat, Kalimantan Tengah, pada bulan juni 2016. Objek dalam penelitian adalah habitat buaya senyulong (Tomistoma schlegelii) di Sungai Sekonyer yang terdiri dari habitat terrestrial dan habitat perairan yang meliputi tempat bersarang, tempat mencari makan dan tempat berjemur, adapun alat dalam penelitian Tali plastik, Meteran, Kompas, Parang, Teropong, 
Thermometer, Hygrometer, Kamera, $\mathrm{Ph}$ meter, Peta lokasi, GPS dan Speedboat.

\section{Pelaksanaan Penelitian}

Untuk mengetahui gambaran mengenai habitat darat buaya senyulong (Tomistoma schlegelii) di Sungai Sekonyer dengan panjang $\pm 49 \mathrm{~km}$ yaitu dengan Metode penelitian pembuatan plot yang dilakukan secara Purposive Sampling di lokasi yang ada perjuumpaan buaya ataupun bekas sarang, sedangkan untuk analisis vegetasinya menggunakan metode petak

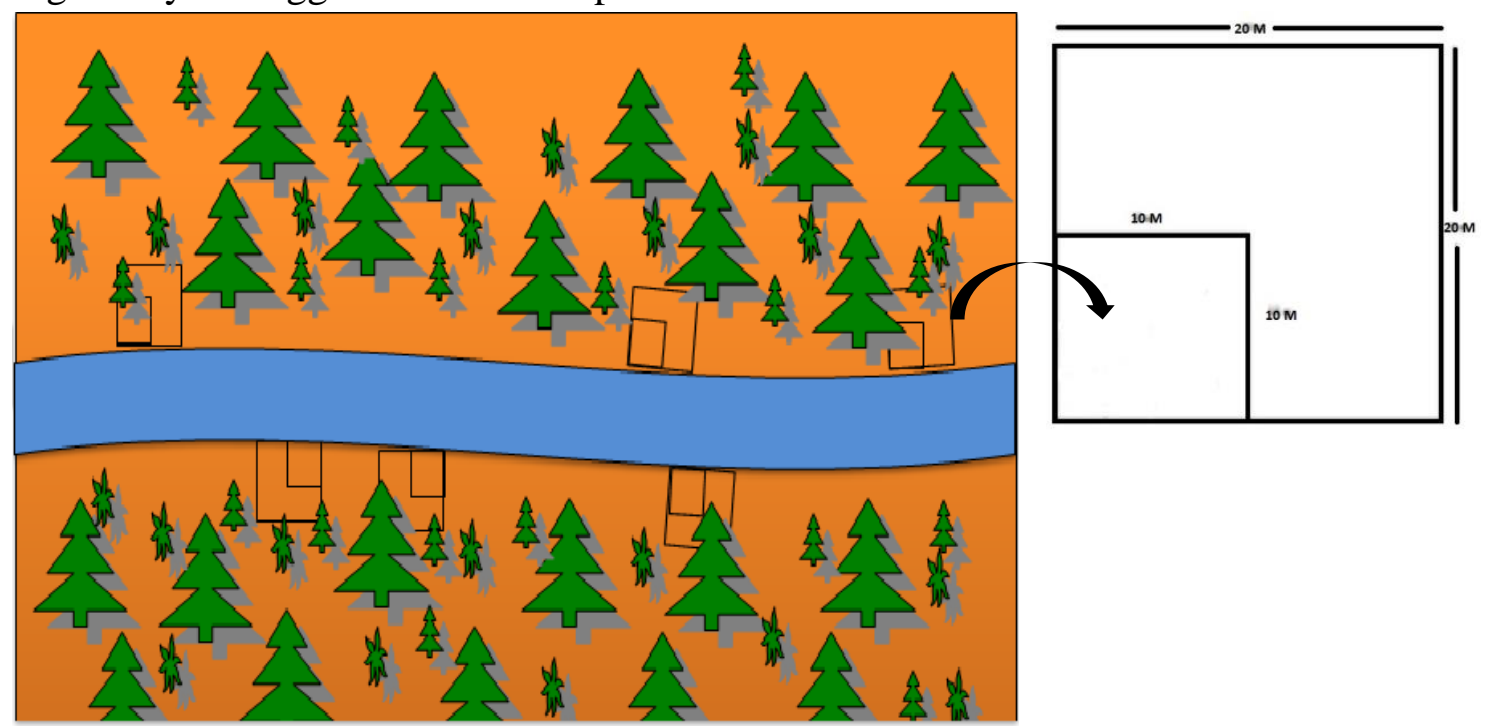

kuadrat berganda yaitu dengan membuat titik pengamatan tiang dan pohon diukur dari bibir sungai ke daratan dengan ukuran petak $20 \mathrm{~m}$ x 20 m untuk tingkat pohon dan $10 \times 10 \mathrm{~m}$ untuk tingkat tiang. Pengambilan titik pengamatan dengan pertimbangan bahwa lokasi tersebut dianggap sebagai habitat buaya senyulong dan jalur pengamatan diletakkan di sepanjang tepian sungai dan diambil sebanyak 8 petak pengamatan.

Gambar 1: Sketsa metode penelitian (Research method sketch)

Keterangan:

A. Tingkat tiang : ukuran $10 \mathrm{~m} \times 10 \mathrm{~m}$

B. Tingkat pohon : ukuran $20 \times 20 \mathrm{~m}$

\section{Analisis data}

Data yang diperoleh dari hasil pengamatan pada masing-masing lokasi habitat buaya senyulong (Tomistoma Schlegelii) terutama data abiotik dan biotik dilapangan seperti kelembaban udara, jenis tanah, derajat keasaman tanah tekstur tanah, komposisi vegetasi dicatat dalam tally sheet. Analisa untuk mengetahui besaran-besaran masing- masing parameter dan keterkaitannya yang kemudian dianalisa secara deskriptif. Untuk habitat perairan seperti derajat keasaman air, warna air, suhu air, jenis ikan dan semua data diambil pada daerah pengamatan yang menjadi habitat buaya.

Diperlukan analisa vegetasi karena kebanyakan sarang di Sumatera dan Kalimantan berada di bawah pohon- 
pohon besar dihutan rawa gambut matang, bersama anak sungai terpencil (Endert 1927, Bezuijen et al. 2001, Stanniewicz 2011). Data didapat dari hasil pengamatan pada masing-masing lokasi habitat buaya dilapangan, kemudian dicatat kedalam tally sheet, dan data yang diambil adalah vegetasi tingkat tiang dan pohon.

Kriteria yang diambil untuk membedakan tingkat pertumbuhan dikutip dari Soerianegara dan Irawan sebagai berikut :

1. Tingkat tiang dengan diameter $10 \mathrm{~cm}$ $-19,99 \mathrm{~cm}$.

2. Tingkat pohon dengan diameter 20 $\mathrm{cm}$ - keatas.

Data yang diperoleh dianalisa dengan rumus perhitungan indeks nilai penting (INP), Indeks dominansi $(C)$, Indeks kenekaragaman jenis $(H)$, Indeks kelimpahan jenis (e), dan Indeks kesamaan jenis. Data ini dipergunakan untuk mengetahui data biotik daratan di sungai Sekonyer.

Pengamatan juga meliputi tumbuhan air seperti bakung dan rasau untuk mengetahui pengaruh tumbuhan air terhadap kelangsungan hidup buaya senyulong di Sungai Sekonyer pengamatan dilakukan secara deskriptif.

\section{HASIL DAN PEMBAHASAN}

\section{Habitat perairan}

Habitat perairan merupakan tempat dimana buaya sangat bergantung sekali dengan air yang dimana air memiliki peran penting sebagai media hidup buaya senyulong.

\section{Data Abiotik}

Abiotik merupakan komponen komponen fisika dan kimia yang tidak hidup dari suatu lingkungan yang dapat mempengaruhi organisme hidup serta berlangsungnya suatu ekosistem merupakan faktor penting dalam ekosistem yang memiliki karakter tertentu untuk mendukung terbentuknya ekosistem. Abiotik dapat berpengaruh secara langsung maupun tidak langsung terhadap kelangsungan hidup dan juga reproduksi setiap makhluk hidup atau organisme salah satunya buaya senyulong. Berikut diantaranya komponen abiotik tersebut:

Tabel 1. Data Biotik Perairan di Sungai Sekonyer (Abiotic water data in Sekonyer River).

\begin{tabular}{llcc}
\hline No & Parameter & Satuan & Nilai Parameter \\
\hline 1 & pH Air & - & 6 \\
2 & Kedalaman Air & Meter & 4,5 \\
3 & Suhu Air & ${ }^{\circ} \mathrm{C}$ & 23,90 \\
\hline
\end{tabular}

Data abiotik perairan di sungai Sekonyer yaitu dengan kandungan $\mathrm{pH}$ air dengan nilai 6 yang menunjukkan netral. Sungai sekonyer memiliki kedalaman ratarata 4,5 meter dan memiliki suhu air $23,90^{\circ} \mathrm{C}$. Kondisi ini memperlihatkan bahwa kualitas air masih baik dan dengan kedalama rata-rata 4,5 meter mengindasikan air mengalir tenang dan perairan yang tenang merupakan tempat ideal untuk kelangsungan hidup buaya Senyulong. 


\section{Data Biotik}

Data Jenis Biota Perairan di Sungai Sekonyer diantaranya adalah seperti Baung (Mystus wyckii), Kapuhung (Ombok leichantos), Patung (Pristolepis grooti), Seluang (Rasbora cephataena), Lais (Lais hexamena), Toman (Channa gachua), Sepat (Trichogaster Trichopteru), Lele (Clarias leicanthus), Kerandang (Channa plurophthalmus), Kapar, Safil, Gabus (Channa striata), Tembubuk (Nandus nebolosus), Runtu (Channa lucius). Perairan merupakan habitat utama dari bagi buaya Senyulong sehingga ikan merupakan pakan utama dalam kelangsungan hidup mereka.

\section{Habitat Darat}

Buaya Senyulong tidak sepenuhnya hidup di perairan umumnya disiang hari mereka menghabiskan waktunya untuk hidup didarat, tujuannya adalah untuk menstabilkan suhu tubuhnya karena tubuh senyulong bersifat ektoterma atau berdarah dingin.

\section{Data Abiotik}

Data abiotik darat merupakan komponen fisika dan kimia yang tidak hidup dari suatu lingkungan yang dapat mempengaruhi organisme hidup serta berlangsungnya suatu ekosistem merupakan faktor penting dalam ekosistem yang memiliki karakter tertentu untuk mendukung terbentuknya ekosistem yang berada di daratan. Berikut data abiotik :

Tabel 2. Data Fisik dan Kimia Darat Habitat Senyulong (Physical Data and Terrestrial Chemical Senyulong Habitat).

\begin{tabular}{|c|c|}
\hline Satuan & Nilai Parameter \\
\hline Tekstur Tanah & Liat berpasir (Sandy-Clay) \\
\hline Jenis Tanah & Histosol \\
\hline Derajat Keasaman Tanah & 6 \\
\hline Kelembaban Udara & $78 \%$ \\
\hline Suhu Rata-rata & $29 \mathrm{C}$ \\
\hline Data fisik dan kimia darat di Sungai & rawa dengan kanopi yang sangat rapat \\
\hline Sekonyer menunjukkan kondisi abiotik & dan suhu rata-rata $29^{\circ} \mathrm{C}$ sangat baik bagi \\
\hline tekstur tanah liat berpasir dengan jenis & menstabilkan \\
\hline tanah yang histosol mengandung bahan & tubuhnya. Data fisik dan kimia darat \\
\hline organik tinggi terbentuk dari sisa-sisa & habitat Senyulong diatas sangat \\
\hline tumbuhan mati yang terdekomposisi & mendukung dalam kelangsungan hidup \\
\hline sehingga menjadi media tumbuh yang & buaya Senyulong. \\
\hline baik untuk regenerasi tumbuhan & Data Biotik \\
\hline disepanjang tepian sungai. Tanah di & Kawasan di sungai Sekonyer, \\
\hline habitat darat memiliki derajat keasaman & memiliki keanekaragaman jenis flora \\
\hline tanah 6 menunjukkan $\mathrm{pH}$ normal dan & sehingga keberadaan \\
\hline memiliki kelembaban udara $78 \%$ & vegetasi hutan ini menjadi komponen \\
\hline menunjukkan kelembaban yang cukup & pendukung bagi buaya senyulong \\
\hline tinggi karena lokasi penelitian di hutan & (Tomistoma schlegelii). \\
\hline
\end{tabular}


Tabel 3. Jenis-jenis Tumbuhan Tingkat Tiang dan Pohon yang ditemukan Dalam Habitat Senyulong Di Sungai Sekonyer (Plants Species that Found at Senyulong Habitat in Sekonyer River).

\begin{tabular}{clll}
\hline No & \multicolumn{1}{c}{ Nama Lokal } & \multicolumn{1}{c}{ Ilmiah } & \multicolumn{1}{c}{ Family } \\
\hline 1 & Ubar & Syzgium attenuatum & Myrtaceae \\
2 & Mampai & Crudia teysmannii & Fabaceae \\
3 & Banitan Kuning & Polyalthia lateriflora & Annonaceae \\
4 & Kumpang & - & - \\
5 & Ketiaw & Syzgium glaucum & Myrtaceae \\
6 & Gembor & - & - \\
7 & Bentan & - & - \\
8 & Rengas & Gluta renghas & Anacardiaceae \\
9 & Medang & Actionodaphne Sp. & Lauraceae \\
10 & Pisulan & Pternandra caerulescens & Melastomaceae \\
11 & Keranji & - & - \\
12 & Habu-habu & Symplocos celastrifolia & Symplocaceae \\
13 & Puak & Artocarpus anisophyllus & Moraceae \\
14 & Lanan & - & - \\
15 & PelerWarik & - & - \\
16 & Papung & Sandoricum einarginatum & Meliaceae \\
17 & Rangda & Blumeodendron tokbrai & - \\
18 & Sesambil Unsung & - & - \\
19 & Rasak & Vatica oblongata & Dipterocarpaceae \\
20 & Jampang & - & - \\
21 & Penaga & - & - \\
22 & Bintuka & - & - \\
23 & Blangeran & Shorea balangeran & Dipterocarpaceae \\
\hline
\end{tabular}

Hasil penelitian di sungai sekonyer di temukan 23 jenis tumbuhan penyusun hutan yang terdiri dari tingkat Tiang dan Pohon. Dari hasil pengamatan tersebut dapat diketahui Kerapatan, Frekuensi, Dominansi, Indeks Nilai Penting, Indeks Keragaman Jenis, serta Indeks Kelimpahan Jenis di lokasi. Indeks Nilai Penting (INP)
Indeks Nilai Penting (INP) ini digunakan untuk menetapkan dominasi suatu jenis terhadap jenis lainnya atau dengan kata lain nilai penting menggambarkan kedudukan ekologis suatu jenis dalam komunitas.

\section{Tingkat Tiang}

Pengambilan tingkat tiang diambil pada tumbuhan muda berdiameter 10 $\mathrm{cm}$ sampai kurang dari $20 \mathrm{~cm}$. 
Tabel 4. Rekapitulasi Hasil INP Tingkat Tiang(Results Recapitulation of Important Value Index Pool Level)

\begin{tabular}{clcccccccc}
\hline No & $\begin{array}{c}\text { Nama } \\
\text { Jenis }\end{array}$ & $\begin{array}{c}\text { Jml } \\
\text { Ind }\end{array}$ & K & KR (\%) & F & FR (\%) & D & DR (\%) & INP \\
\hline \hline 1 & Ubar & 8 & 61,53 & 21,62 & 0,38 & 18,51 & 0,96 & 22,20 & 62,34 \\
2 & Rengas & 1 & 7,69 & 2,70 & 0,07 & 3,70 & 0,13 & 3,10 & 9,51 \\
3 & Gembor & 1 & 7,69 & 2,70 & 0,07 & 3,70 & 0,18 & 4,25 & 10,65 \\
4 & Ketiaw & 2 & 15,38 & 5,40 & 0,23 & 11,11 & 0,34 & 7,85 & 24,37 \\
5 & Medang & 1 & 7,69 & 2,70 & 0,07 & 3,70 & 0,07 & 1,66 & 8,07 \\
6 & Habu & 8 & 61,53 & 21,62 & 0,23 & 11,11 & 0,86 & 19,95 & 52,69 \\
7 & Puak & 4 & 30,76 & 10,81 & 0,23 & 11,11 & 0,38 & 8,94 & 30,86 \\
8 & Rangda & 1 & 7,69 & 2,70 & 0,07 & 3,70 & 0,06 & 1,57 & 7,98 \\
9 & Pisulan & 2 & 15,38 & 5,40 & 0,15 & 7,40 & 0,18 & 4,25 & 17,06 \\
10 & Sesambil & 1 & 7,69 & 2,70 & 0,07 & 3,70 & 0,12 & 2,92 & 9,33 \\
11 & Mampai & 2 & 15,38 & 5,40 & 0,07 & 3,70 & 0,20 & 4,68 & 13,79 \\
12 & Blangiran & 2 & 15,38 & 5,40 & 0,07 & 3,70 & 0,27 & 6,42 & 15,53 \\
13 & Jampang & 2 & 15,38 & 5,40 & 0,15 & 7,40 & 0,25 & 5,77 & 18,59 \\
14 & Bentan & 1 & 7,69 & 2,70 & 0,07 & 3,70 & 0,16 & 3,68 & 10,09 \\
15 & Penaga & 1 & 7,69 & 2,70 & 0,07 & 3,70 & 0,11 & 2,69 & 9,09 \\
\hline
\end{tabular}

Jenis yang mendominasi tingkat tiang di sungai Sekonyer adalah jenis Ubar dengan INP sebesar 62,34\%, Habu-habu sebesar 52,69\%, Puak sebesar $30,86 \%$ dan ketiaw sebesar 24,37 , artinya ketiga jenis tingkat tiang a. Tingkat pohon

Tabel 5.Rekapitulasi Hasil INP Tingkat Pohon (Results Recapitulation of Important Value Index Tree Level).

\begin{tabular}{clcccccccc}
\hline No & $\begin{array}{c}\text { Nama } \\
\text { Jenis }\end{array}$ & $\begin{array}{c}\text { Jml } \\
\text { Ind }\end{array}$ & $\mathbf{K}$ & $\begin{array}{c}\text { KR } \\
(\boldsymbol{\%})\end{array}$ & $\mathbf{F}$ & $\mathbf{F R}(\boldsymbol{\%})$ & $\mathbf{D}$ & $\mathbf{D R}(\boldsymbol{\%})$ & $\mathbf{I N P}$ \\
\hline \hline 1 & Medang & 1 & 7,69 & 1,78 & 0,07 & 2,70 & 0,40 & 1,03 & 5,518 \\
2 & Ketiaw & 18 & 138,46 & 32,14 & 0,61 & 21,62 & 16,18 & 41,57 & 95,34 \\
3 & Rengas & 7 & 53,84 & 12,50 & 0,38 & 13,51 & 5,95 & 15,28 & 41,29 \\
4 & Pisulan & 4 & 30,76 & 7,14 & 0,15 & 5,40 & 3,57 & 9,17 & 21,72 \\
5 & Warik & 1 & 7,69 & 1,78 & 0,07 & 2,70 & 0,42 & 1,08 & 5,56 \\
6 & Papung & 1 & 7,69 & 1,78 & 0,07 & 2,70 & 0,39 & 1,00 & 5,49 \\
7 & Mampai & 4 & 30,76 & 7,14 & 0,30 & 10,81 & 1,64 & 4,22 & 22,18 \\
8 & Puak & 1 & 7,69 & 1,78 & 0,07 & 2,70 & 0,37 & 0,95 & 5,44 \\
9 & Rangda & 1 & 7,69 & 1,78 & 0,07 & 2,70 & 0,42 & 1,08 & 5,56 \\
10 & Rasak & 1 & 7,69 & 1,78 & 0,07 & 2,70 & 0,29 & 0,76 & 5,25 \\
11 & Banditan & 2 & 15,38 & 3,57 & 0,07 & 2,70 & 1,02 & 2,64 & 8,91 \\
12 & Kumpang & 1 & 7,69 & 1,78 & 0,07 & 2,70 & 0,34 & 0,89 & 5,38 \\
13 & Ubar & 2 & 15,38 & 3,57 & 0,15 & 5,40 & 0,74 & 1,90 & 10,88 \\
14 & Habu & 5 & 38,46 & 8,92 & 0,15 & 5,40 & 1,68 & 4,31 & 18,65 \\
15 & Blangiran & 3 & 23,07 & 5,35 & 0,15 & 5,40 & 1,79 & 4,60 & 15,36 \\
16 & Keranji & 1 & 7,69 & 1,78 & 0,07 & 2,70 & 0,24 & 0,63 & 5,12 \\
17 & Lanan & 1 & 7,69 & 1,78 & 0,07 & 2,70 & 1,98 & 5,086 & 9,57 \\
18 & Bentan & 1 & 7,69 & 1,78 & 0,07 & 2,70 & 0,27 & 0,704 & 5,19 \\
19 & Bintuka & 1 & 7,69 & 1,78 & 0,07 & 2,70 & 1,18 & 3,033 & 7,52 \\
\hline
\end{tabular}


Jenis Ketiaw sebesar 95,34 \%, Rengas sebesar 41,29\%, mampai sebesar 22,18\%, artinya ketiga jenis tingkat pohon ini merupakan spesies yang paling dominan dan paling menonjol serta berkuasa diantara spesies yang ada dan pohon ini memang hidup di rawa gambut dimana sesuai dengan list tumbuhan yang hidup di rawa gambut (Ripin, 2017) dan tempat tumbuh memang ideal antara pertemuan rawa gambut dan mineral, ini juga menjadi habitat yang baik bagi buaya Senyulong.

Indeks Dominansi (C), Indeks Keanekaragaman Jenis (H), Indeks Kelimpahan Jenis (e).

Tabel 6. Rekapitulasi Total Indeks Dominansi (C) (Total Recapitulation Dominance Index), Rekapitulasi Total Indeks Keanekaragaman Jenis (H) (Total Recapitulation Diversity Index), Rekapitulasi Total Indeks Kelimpahan Jenis (e) (Total Recapitulation Abundance Index).

\begin{tabular}{lcclcc}
\hline $\begin{array}{c}\text { Tingkat } \\
\text { Vegetasi }\end{array}$ & $\begin{array}{c}\text { Jumlah } \\
\text { Jenis }\end{array}$ & $\begin{array}{c}\text { Jumlah } \\
\text { Individu }\end{array}$ & (C)Total & (H) Total & (e) Total \\
\hline Tiang & 15 & 37 & 0,1098 & 1,06 & 0,90 \\
Pohon & 19 & 56 & 0,1439 & 0,99 & 0,77 \\
\hline \multicolumn{1}{c}{ Indeks dominan di } & Sungai & vegetasi di rawa gambut memang \\
Sekonyer dapat dikatakan rendah yang & sedikit, & \\
ditunjukkan dengan nilai C $=0$, yaitu & Indeks kelimpahan jenis (e) pohon \\
untuk tingkat Tiang adalah 0,10 dan & secara umum dapat dikatan bahwa \\
tingkat Pohon 0,14. Artinya bahwa & untuk semua tingkatan pertumbuhan \\
vegetasi hutan di Sungai Sekonyer tidak & merata dan ditunjukkan dengan nilai \\
hanya satu jenis saja yang yang & mendekati 1, yaitu tingkat tiang 0,90 \\
dominan terhadap jenis yang lain & dan tingkat pohon 0,7798, hal ini \\
sehingga kondisi demikian dapat & disebabkan karena \\
diartikan bahwa dinamika masyrakat & tumbuhan bereproduksi, persebaran \\
tumbuhan masih dapat terus berjalan & benih, dan tingkat adaptasi sangat \\
sampai pada tahap dimana suatu jenis & tinggi.
\end{tabular}
nantinya dapat menguasi daerah tersebut.

Index keanekaragaman jenis $(\mathrm{H})$ vegetasi di Sungai Sekonyer tingkat tiang memiliki nilai indeks 1,06 menunjukkan nilai indeks keanekaragaman spesiesnya cukup karena > 1, sedangkan tingkat Pohon memiliki indeks nilai 0,99 menunjukkan vegetasi di sungai Sekonyer memiliki keanekaragaman rendah karena $<1$ itu disebabkan karena komposisi jenis

\section{Komponen Habitat Buaya}

Beberapa komponen penting habitat buaya senyulong (Tomistoma schlegelii) sebagaimana disebutkan oleh Suwanto (1989) yaitu tempat mencari makan, tempat bertelur dan bersarang, tempat berlindung dan tempat berjemur. Komponen-komponen habitat tersebut dapat dikenal dari penelitian di lapangan dan hasil wawancara dengan masyarakat setempat, dapat dijelaskan sebagai berikut. 
Tempat Mencari Makan

Sungai Sekonyer merupakan sungai yang cukup lebar dan dalam, sepanjang perairan banyak ditemukan lubuk-lubuk yang ditutupi oleh rimbunan pohon dan rumput-rumputan yang merupakan tempat yang disukai oleh ikan-ikan untuk berkembang biak. Berdasarkan informasi dan dari masyarakata dan petugas Taman Nasional Buaya Senyulong juga dapat memangsa hewan-hewan daratan yang berada disekitar danau antara lain Monyet (Macaca fascicularis), Biawak (Varanus salvator), Orangutan (Pongo pygmaeus), Bekantan (Nasalis larvatus) Babi Hutan (Sus barbatus) dan Kancil (Tragulus sp). Buaya Senyulong adalah hewan penyergap dan penyergapan dilakukan biasanya disaat hewan yang dimangsa sedang minum air dipinggiran sungai dan sedang lengah.

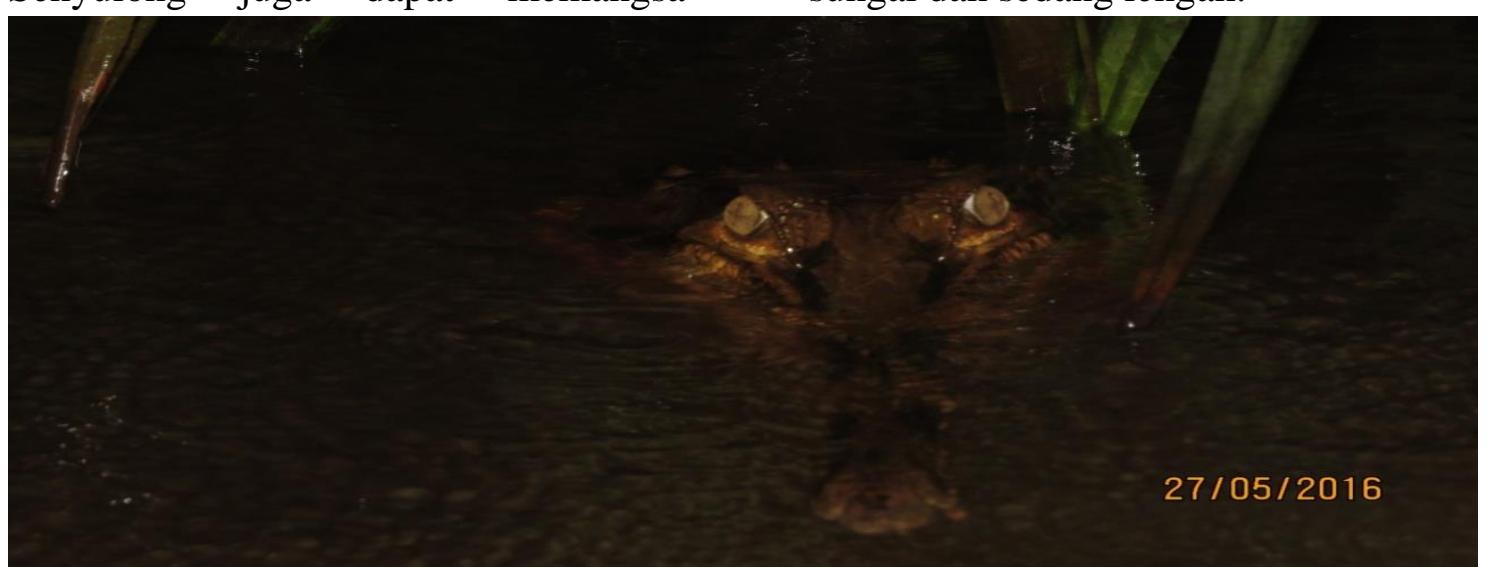

Gambar 2. Buaya Senyulong dewasa yang sedang mencari makan dimalam hari 21:15 WIT.

(Adult Senyulong feeding at night 21:15 WIT).

Tempat Bersarang

Tempat Buaya Senyulong bersarang adalah rawa-rawa yang berdekatan dengan bibir sungai dan menyukai daratan yang banyak timbunan serasah daun dan ranting dan naungan pohon. Serasah ini berfungsi sebagai sumber panas yang dibutuhkan telur agar suhu tetap stabil dan membantu mempercepat proses penetasan telur dan buaya senyulong biasanya menempatkan sarangnya di bawah banir.

\section{Tempat berlindung}

Sepanjang tepian Sungai Sekonyer banyak ditumbuhi oleh jenis flora seperti Rasau (Pandanus Tectorious),
Bakung (Hanguana malayana), Kumpai (sorghum oropinguium). Dengan melihat karakteristik tepian Sungai Sekonyer yang Rimbun menjadikan tempat berlindung ideal tempat bermain bagi anakan buaya Senyulong.

\section{Tempat berjemur}

Tepian Sungai Sekonyer umumnya ditutupi oleh vegetasi bawah seperti rumput-rumputan yang hidup di sepanjang sungai Sekonyer dan juga terdapat tanah lapang yang tak ditumbuhi. Pada umumnya buaya berjemur pada daratan dan berjemur di pohon tumbang yang disinari matahari langsung untuk menstabilkan suhu 
tubuhnya karena tubu buaya bersifat ektoterma atau berdarah dingin.

\section{Gangguan Terhadap Populasi Buaya dan Habitatnya}

Keberadaan buaya Senyulong masih mudah dijumpai, Secara keseluruhan di lokasi penelitian populasi buaya tidak mengalami penurunan, kondisi habitat masih relatif baik jika dilihat dari keadaan sifat fisik kimia perairan, daratan jenis vegetasi serta satwa-satwa yang ada di daratan maupun perairan.Sungai Sekonyer telah mengalami gangguan tapi pengaruhnya terhadap kelangsungan buaya masih bisa beradapatasi. Adapun gangguangangguan tersebut diantaranya:

\section{Penebangan pohon}

Penebangan pohon di sungai Sekonyer hanyalah dilakukan untuk skala rumah saja seperti untuk membuat di dinding rumah, tiang-tiang rumah dan bangunan lainnya namun, apabila dilakukan secara terus menerus maka akan mengganggu habitat buaya tersebut, mengingat sebagian besar buaya membuat sarang berada di bawah pohon-pohon besar.

\section{Lalu Lintas Perairan}

Lalu lintas perairan di Sungai Sekonyer didominasi oleh kapal air/klotok wisatawan yang bekunjung ke Taman Nasional Tanjung Puting pada setiap harinya, lalu lintas ini juga dapat juga memberikan gangguan kepada buaya sehingga bisa menyebabkan buaya menjadi stres dan mengganggu perkembangan buaya yang hidup di sungai Sekonyer. Lalu lintas klotok hanya diperbolekan mulai pagi sampai sore saja.

Perburuan Buaya

Perburuan Buaya juga sering terjadi disana, menurut para nelayan yang mencari ikan disana mereka pernah melihat oknum yang sedang melakukan perburuan buaya Senyolong, buaya tersebut diambil dagingnya untuk dimakan. Tindakan ini sungguh sangat disayangkan sekali mengingat apabila kegiatan perburuan ini terus menerus dilakukan maka akan mengancam populasi dari buaya Senyulong tersebut. Pertambangan Ilegal

Aktivitas pertambangan illegal terjadi di hulu sungai Sekonyer, berdampak pada sungai sekonyer menjadi keruh dari hulu akan terus mengalir ke hilir tentu saja ini akan mengganggu habitat dan kelangsungan hidup buaya, kegiatan pertambangan ilegal ini dilakukan mulai dari pagi sampai sore hari. Sebenarnya kegiatan pertambangan ilegal ini sering dilakukan sidak kelapangan oleh pihak Taman Nasional, BKSDA dan Aparat Kepolisian setempat, untuk melarang kegiatan tersebut, namun mereka tetap mengulangi kembali kegiatan pertambangan ilegal tersebut.

\section{Kesimpulan}

Habitat Buaya Senyulong di Sungai Sekonyer dapat dibagi dalam dua bagian yaitu habitat perairan dan habitat darat.

\section{Habitat Perairan}

Sungai Sekonyer memiliki pH air 6 dengan kedalaman rata-rata 4,5 meter dan suhu air $23^{\circ} \mathrm{C}$. Perairan merupakan 
habitat utama Buaya Senyulong (Tomistoma schlegelii), jenis tumbuhan air seperti Rasau (Pandanus tectorius), Bakung air (Hanguana malayana) dan Kumpai (sorghum oropinguium) yang hidup di pinggiran sungai dijadikan sebagai tempat berlindung. Jenis ikan ukuran besar menjadi sumber pakan buaya Senyulong.

\section{Habitat Darat}

Daratan sekitar sungai Sekonyer yang menjadi habitat Buaya Senyulong memiliki tekstur tanah liat berpasir (Sandy-Clay) dengan jenis tanah histosol yang memiliki derajat keasaman tanah 5-6 dan kelembaban udara $78 \%$ dengan suhu rata-rata $29^{\circ} \mathrm{C}$, bufferzone berupa pohon-pohon besar yang memiliki tajuk lebar seperti jenis Ketiaw (Syzgium glaucum). Sedikitnya ada 23 jenis tumbuhan di hutan rawa dan daratan sungai Sekonyer yang menjadi habitat buaya Senyulong.

\section{Saran}

Perlu Penelitian tentang pertambangan ilegal dan kegiatan lainnyayang berada di sungai Sekonyer terhadap kelestarian habitat buaya Senyulong untuk mendukung dan memperkaya khasanah ilmu pengetahuan guna menjaga kelangsungan hidup buaya Senyulong.

\section{DAFTAR PUSTAKA}

Bezuijen, M.R, Shwedick, B., Simpson, B.K, Stanleweicz, A. dan Stuebing. 2014. (Tomistoma Schlegelii). The IUCN Red List of threatened Species 2014 : e. T21981A2780499.

Ripin, Dwi Astiani, Burhanuddin. 2017. Jenis-Jenis Pohon Penyusun
Vegetasi Hutan Rawa Gambut Di Semenanjung Kampar Kecamatan Teluk MerantiProvinsi Riau, Jurnal Hutan LestariVol. 5 (3) : 807 813.

Soerianegara, I. Dan A.Indrawanan. 1982. Ekologi Hutan Indonesia. Bogor : Departemen Manajemen Hutan Fakultas Kehutanan Institut Pertanian Bogor.

Stuebing, R.B., Bezuijen, Bezuijen, M.R., Aulia, M. And Voris, H.K. 2006. The Current and Historic Distribution of Tomistoma schlegelii (the False Gharial) (Muller 1838) (Crocodilia, Reptilia). The Raffles of Zoology 54: 181 197.

Auliya, M., B. Shwedick, R. Sommerlad, S. Brend \& Samedi 2006: A short-term assessment of the conservation status of (Tomistoma schlegelii) (Crocodylia:Crocodylidae) in Tanjung Puting National Park (Central Kalimantan, Indonesia). A cooperative survey by the Orangutan Foundation (UK) and the Tomistoma Task Force, of the IUCN/SSC Crocodile Specialist Group. 